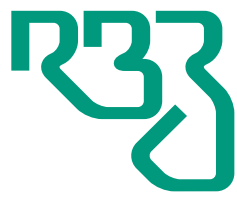

Revista

Brasileira de

Zootecnia

Brazilian Journal of Animal Science

ISSN 1806-9290

www.rbz.org.br

\title{
Mathematical models to predict growth, fillet traits, and composition of wild traíra, Hoplias malabaricus
}

\author{
Valéria Rossetto Barriviera Furuya ${ }^{1}$ (iD), Mariana Michelato ${ }^{2}$ (iD), Ana Lúcia \\ Salaro $^{3}$ iD, Thais Pereira da Cruz ${ }^{1}$ iD, Allan Vinnícius Urbich ${ }^{1}$ iD, Jonathan \\ Willian Andrade Ribeiro $^{1}$ (iD, Dayane Cheritt Batista ${ }^{1}$ (ID, Wilson \\ Massamitu Furuya ${ }^{1^{*}}$ iD \\ ${ }^{1}$ Universidade Estadual de Ponta Grossa, Departamento de Zootecnia, Ponta Grossa, \\ PR, Brasil. \\ ${ }^{2}$ Universidade Estadual de Maringá, Programa de Pós-Graduação em Zootecnia, Maringá, \\ PR, Brasil. \\ ${ }^{3}$ Universidade Federal de Viçosa, Departamento de Biologia, Viçosa, MG, Brasil.
}

\section{*Corresponding author: \\ wmfuruya@uepg.br \\ Received: June 24, 2017 \\ Accepted: April 3, 2019}

How to cite: Furuya, V. R. B.; Michelato, M.; Salaro, A. L.; Cruz, T. P.; Urbich, A. V.; Ribeiro, J. W. A.; Batista, D. C. and Furuya, W. M. 2019. Mathematical models to predict growth, fillet traits, and composition of wild traíra, Hoplias malabaricus. Revista Brasileira de Zootecnia 48:e20170176.

https://doi.org/10.1590/rbz4820170176

Copyright: This is an open access article distributed under the terms of the

Creative Commons Attribution License (http://creativecommons.org/licenses/by/4.0/), which permits unrestricted use, distribution, and reproduction in any medium, provided the original work is properly cited.

\begin{abstract}
This study aimed to determine the length-weight relationship and mathematical models to predict dressed and fillet weight and yield and fillet composition of wild traíra, Hoplias malabaricus (Bloch, 1794). A total of 80 marketable-sized fish from 292.28 to $2879.57 \mathrm{~g}$ and 32.06 to $61.19 \mathrm{~cm}$ were used. The length:weight ratio was estimated using the equation: $W=a \times L^{\mathrm{b}}$, in which $W$ is body weight (g) and $L$ is length $(\mathrm{cm})$. The models of dressed and fillet weight and yield and body were elaborated using first-order $\left(\hat{y}_{\mathrm{i}}=\beta 0+\beta 1 x_{\mathrm{i}}\right)$ or second-order $\left(\hat{y}_{\mathrm{i}}=\beta 0+\beta 1 x_{\mathrm{i}}+\beta 1 x_{\mathrm{i}}^{2}\right)$ linear regression analyses. The value of slope $b$ in the length:weight ratio was 3.3732 and intercept was 0.0029 . The prediction equations obtained for dressed weight, fillet weight, dressed yield, fillet yield, fillet gross energy, moisture, crude protein, crude lipid, and ash were, respectively: $\hat{y}=0.3244+0.9373 W, \hat{y}=0.7651+0.4181 W, \hat{y}=939.8015+$ $0.0019 \mathrm{~W}, \hat{y}=420.55170+0.0064 \mathrm{~W}, \hat{y}=997.9600+0.0630 \mathrm{~W}, \hat{y}=810.6500-0.0085 \mathrm{~W}$, $\hat{y}=184.080-0.0111 W, \hat{y}=3.1131+0.0049 W$, and $\hat{y}=10.6110+0.0009 W$, in which $W$ is the body weight of fish (g). We demonstrated the possibility of elaborating realistic expressions to describe degutted weight, fillet weight, and fillet composition. However, lower mathematical adjustment was observed to estimate realistic prediction of dressed and fillet yield.
\end{abstract}

Keywords: aquaculture, carcass, fish, growth curve, meat quality

\section{Introduction}

Hoplias malabaricus (Bloch, 1794) is a neotropical freshwater fish widely distributed in Latin America (Bertollo et al., 2000) from Colombia to Argentina (Balboni et al., 2011). This fish species inhabits lentic and lotic environments (Silva et al., 2013), is appreciated as sporting fish (Balboni et al., 2011), and fillet of wild fish is known to be rich in protein and polyunsaturated fatty acids (Torres et al., 2012).

Growth is characterized by change in size and tissue composition, and is one the most important parameter in aquaculture. The body composition of fish has been received attention in studies on nutrition (Dumas et al., 2010), genetics improvement (Gjedrem, 2000; Tobin et al., 2006), human health (Hunter and Roberts, 2000), and particularly because of increasing interest in fish quality and safety products (Mozaffarian and Rimm, 2006) to ensure the nutritional quality of fish (Azam et al., 2004). Carcass traits of fish has also been used to estimate and introduce selection program (Quinton et al., 
2005; Navarro et al., 2009). Body composition and carcass traits are markedly influenced by fish species and size and considered as priority variable in fish processing industry (Neira et al., 2004).

Although several studies have evaluated the biology of growth (Balboni et al., 2011) (Bialetzki et al., 2008), genetics (Cioffi et al., 2009), reproduction (Marques et al., 2001; Querol et al., 2003; Chaves et al., 2011), and feeding habits (Carvalho et al., 2003), only a single study has evaluated the proximate composition and fillet yield of $H$. malabaricus (Santos et al., 2001), and this is the first mention of using mathematical modeling to estimate growth, fillet composition, and yield for this fish species.

Building a mathematical model of fish growth offers a robust and practical tool to estimate weight at time between sampling intervals and may be very helpful for the accurate estimation of the standing biomass and feeding allowance during fish culture. Mathematical modelling has been intensively used to elaborate equations to describe or simulate body composition of fish, and linear regression has been proposed to predict body composition of farmed and wild fish (Dumas et al., 2010).

Skin-on fillet of traíra is preferred for cutting bones during processing and preserving fillet integrity before frying. Despite the great social and economic importance of $H$. malabaricus to the South America communities, the usefulness data of length:weight ratio, fillet yield, and composition is poorly documented. Thus, this work was carried out to elaborate mathematical models of growth, dressing and fillet weight, and yield and fillet composition of wild H. malabaricus using linear regression.

\section{Material and Methods}

A total of 80 fish from 292.28 to $2879.57 \mathrm{~g}$ and 32.06 to $61.19 \mathrm{~cm}$, of combined sex, were obtained

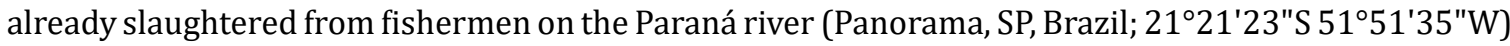
and transported on ice in sealed polystyrene boxes. Combined sexes were preferred to mimic practical conditions of fishing and marketing fish because there are no reliable morphological differences to identify sex in $H$. malabaricus. Individually, total length and body weight were determined using ictiometer $(0.1 \mathrm{~cm})$ and precision balance $(0.01 \mathrm{~g})$, respectively.

Fish were manually gutted and filleted without including the nape and belly flap, and both fillets were weighed together (Navarro et al., 2009), which derived traits of dressed yield (100 × gutted body weight/body weight) and fillet yield (100 $\times$ fillets weight/body weight $)$ that were recorded. Skin-on fillets were obtained and stored in plastic bags at $-20{ }^{\circ} \mathrm{C}$ until laboratorial analysis to determine proximate analysis. Fish processing was performed by the same operator.

Fish fillets were minced, and the proximate composition analyses of each fish samples were performed in duplicate following the AOAC (2010) procedures. Water content was determined by placing the fish in a pre-weighed aluminum foil tray for drying in an electric oven at $55{ }^{\circ} \mathrm{C}$ until constant weight and oven drying at $105^{\circ} \mathrm{C}$ for $24 \mathrm{~h}$; crude protein (nitrogen $\times 6.25$ ) was determined by Kjeldahl method, after acid hydrolysis; lipid was extracted by petroleum ether in a Soxhlet apparatus followed by determination of lipid gravimetrically; and ash was determined by combustion at $550{ }^{\circ} \mathrm{C}$, in a muffle furnace overnight, until constant weight.

Each fish was considered as experimental replicate. Data on total length $(L)$ in $\mathrm{cm}$, and body weight $(W)$ in $\mathrm{g}$, were recorded for each fish. The parameters $a$ (intercept) and $b$ (slope ) of the length:weight ratio were estimated using the equation: $W=a \times L^{\mathrm{b}}$ (Ricker, 1973). Parameters $a$ and $b$ were estimated by the least-square method using log-transformed data according to the expression: $\log W=\log a+b \log L$, in which $a$ is the intercept of the regression curve and $b$ is the regression coefficients. The average value for $b$ was tested to verify if it was significantly different from 3 using t test at the $\alpha=0.05$ significance level.

Prediction equations of fillet composition of $H$. malabaricus were elaborated using first-order $\left(\hat{y}_{\mathrm{i}}=\beta 0+\beta 1 x_{\mathrm{i}}\right)$ or second-order $\left(\hat{y}_{\mathrm{i}}=\beta 0+\beta 1 x_{\mathrm{i}}+\beta 1 x_{\mathrm{i}}^{2}\right)$ linear regression analysis. All statistical procedures were performed using SPSS statistical package (Statistical Package for the Social Sciences, version 14.0). 


\section{Results}

The length:weight ratio was established through the equation $W=0.0029 \times L^{3.3732}\left(\mathrm{R}^{2}=0.9614\right)$ (Figure 1). The average value of $b$ was significantly different from $3(\mathrm{P}<0.05)$ according to the $t$ test.

The relationship between dressed and fillet weight to body weight was best fit using first-order linear regression analysis, expressed as: dressed weight $\hat{y}=0.3244+0.9373 W\left(\mathrm{R}^{2}=0.9992\right)$ and fillet weight $\hat{y}=0.7651+0.4181 W\left(R^{2}=0.9599\right)$. However, lower mathematical adjustment between dressed yield and fillet yield to body weight was observed, described according to the expressions: dressed yield $\hat{y}=939.8015+0.0019 W\left(R^{2}=0.0035\right)$ and fillet yield $\hat{y}=420.5517+0.0064 W\left(R^{2}=0.0001\right)$, respectively (Table 1 ).

The relationship between fillet gross energy, moisture, crude protein, crude lipid, and ash to body weight was best expressed using first-order linear regression analysis (Table 2), according to the expressions: gross energy, $\hat{y}=997.9600+0.0630 W\left(\mathrm{R}^{2}=0.8539\right)$; moisture, $\hat{y}=810.6500-0.0085 W\left(\mathrm{R}^{2}=0.7566\right)$; crude protein, $\hat{y}=184.0800-0.0111 W\left(\mathrm{R}^{2}=0.6746\right)$; crude lipid, $\hat{y}=3.1131+0.0049 W\left(\mathrm{R}^{2}=0.8542\right)$; and ash, $\hat{y}=10.6110+0.0009 W\left(\mathrm{R}^{2}=0.7847\right)$.

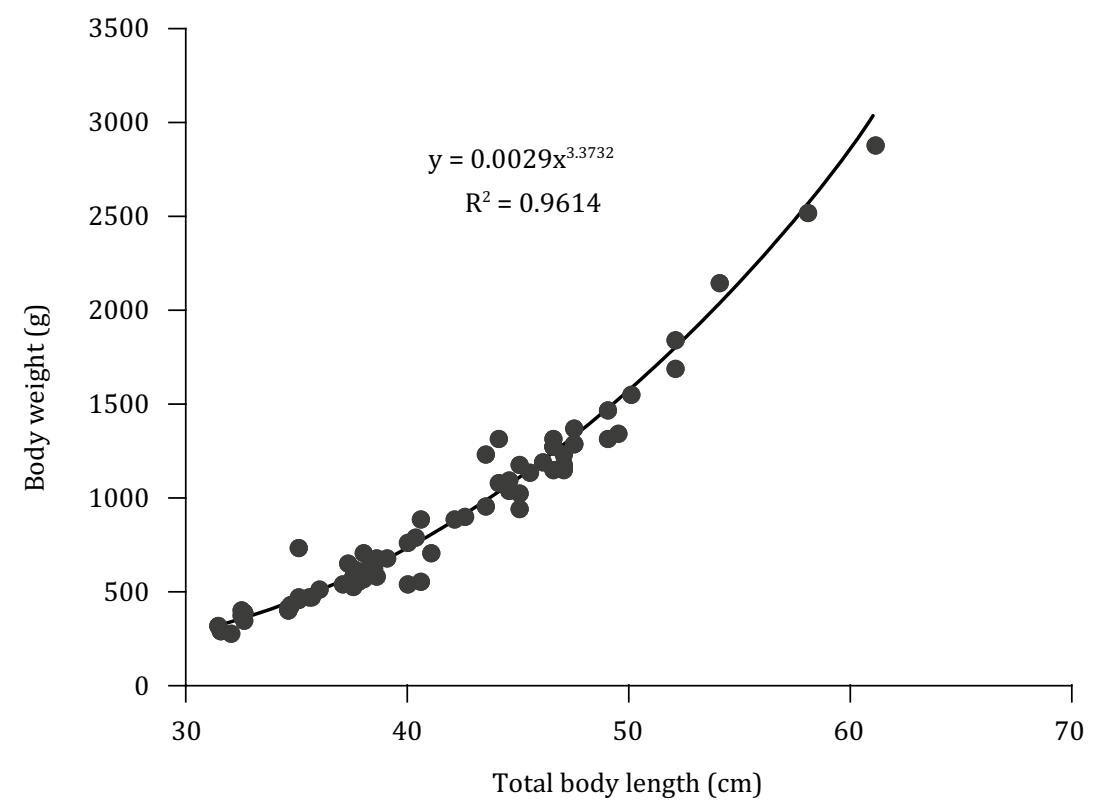

Figure 1 - Length to weight relationship of market-sized wild traíra, Hoplias lacerdae.

Table 1 - Statistical details showing number of fish studied $(n)$, intercept $(\beta 0)$, slope $(\beta 1)$, and coefficient of determination $\left(\mathrm{R}^{2}\right)$ between fillet traits and body weight of market-sized wild Hoplias malabaricus

\begin{tabular}{lcccc}
\hline Item & $\begin{array}{c}\text { Dressed weight } \\
(\mathrm{g})\end{array}$ & $\begin{array}{c}\text { Fillet weight } \\
(\mathrm{g})\end{array}$ & $\begin{array}{c}\text { Dressed yield } \\
(\mathrm{g} / \mathrm{kg})\end{array}$ & $\begin{array}{c}\text { Fillet yield } \\
(\mathrm{g} / \mathrm{kg})\end{array}$ \\
\hline $\begin{array}{l}\text { Body weight } \\
\text { Range }\end{array}$ & & & \\
$\quad$ Mean & $276.33-2678.64$ & $114.63-1253.55$ & $925.96-945.38$ & $358.93-465.11$ \\
Statistical details & 813.81 & 369.62 & 938.63 & 425.23 \\
$n$ & & & & \\
$\beta 0$ & 80 & 80 & 80 & 80 \\
$\beta 1$ & 0.3244 & 0.7651 & 939.8015 & 420.5517 \\
$R^{2}$ & 0.9373 & 0.4181 & 0.0019 & 0.0064 \\
\hline
\end{tabular}


The relationship between fillet humidity and fat was also best fit using first-order linear regression analysis according to the expression: $\hat{y}=408.861-0.4998 x\left(R^{2}=0.8309\right)$ (Figure 2). Except for crude protein, all other linear regressions were highly significant, and the coefficient of determination ranged from 0.8161 to $0.8539(\mathrm{P}<0.05)$.

\section{Discussion}

In the present study, the $b$ value (3.3732) was significantly higher than 3 and the "cube law" could not be applied for this fish species. If growth model of fish follows the "cube law", Fulton's condition factor (k) or isometric factor $\left(k=W / L^{b}\right)$ is validated, the length to weight exponent $b$ value is equal to 3 (Gulland, 1983), and body form remains a constant proportion to length (Weatherley and Gill, 1987). However, Fulton's condition factor is only applied to compare fish of the same size; however, allometric condition factor, which occurs when $b$ is different from 3 , is observed when fish of different stages is used (Braga, 1986). Parameter $b$, unlike parameter $a$, may vary seasonally and the length:weight ratio is affected (Cherif et al., 2008). To date, in this study, only market-sized fish were used; however, length

Table 2 - Statistical details showing number of fish studied $(n)$, intercept $(\beta 0)$, slope $(\beta 1)$, and p-coefficient of determination $\left(\mathrm{R}^{2}\right)$ between fillet composition and body weight of market-sized wild Hoplias malabaricus

\begin{tabular}{lccccc}
\hline Item & $\begin{array}{c}\text { Gross energy } \\
(\mathrm{kcal} / \mathrm{kg})\end{array}$ & $\begin{array}{c}\text { Moisture } \\
(\mathrm{g} / \mathrm{kg})\end{array}$ & $\begin{array}{c}\text { Crude protein } \\
(\mathrm{g} / \mathrm{kg})\end{array}$ & $\begin{array}{c}\text { Crude lipid } \\
(\mathrm{g} / \mathrm{kg})\end{array}$ & $\begin{array}{c}\text { Ash } \\
(\mathrm{g} / \mathrm{kg})\end{array}$ \\
\hline Body composition & & & & & \\
$\quad$ Range & $982.34-1091.34$ & $780-809.10$ & $160.00-188.00$ & $4.10-19.10$ & $10.50-12.30$ \\
$\quad$ Mean & 1046.75 & 803.27 & 174.48 & 7.41 & 11.40 \\
Statistic details & & & & & 80 \\
$n$ & 80 & 80 & 80 & 80 & 10.6110 \\
$\beta 0$ & 997.9600 & 810.6500 & 184.0800 & 3.1131 & 0.0009 \\
$\beta 1$ & 0.0630 & -0.0085 & -0.0111 & 0.0049 & 0.7847 \\
$\mathrm{R}^{2}$ & 0.8539 & 0.7566 & 0.6746 & 0.8542 & \\
\hline
\end{tabular}

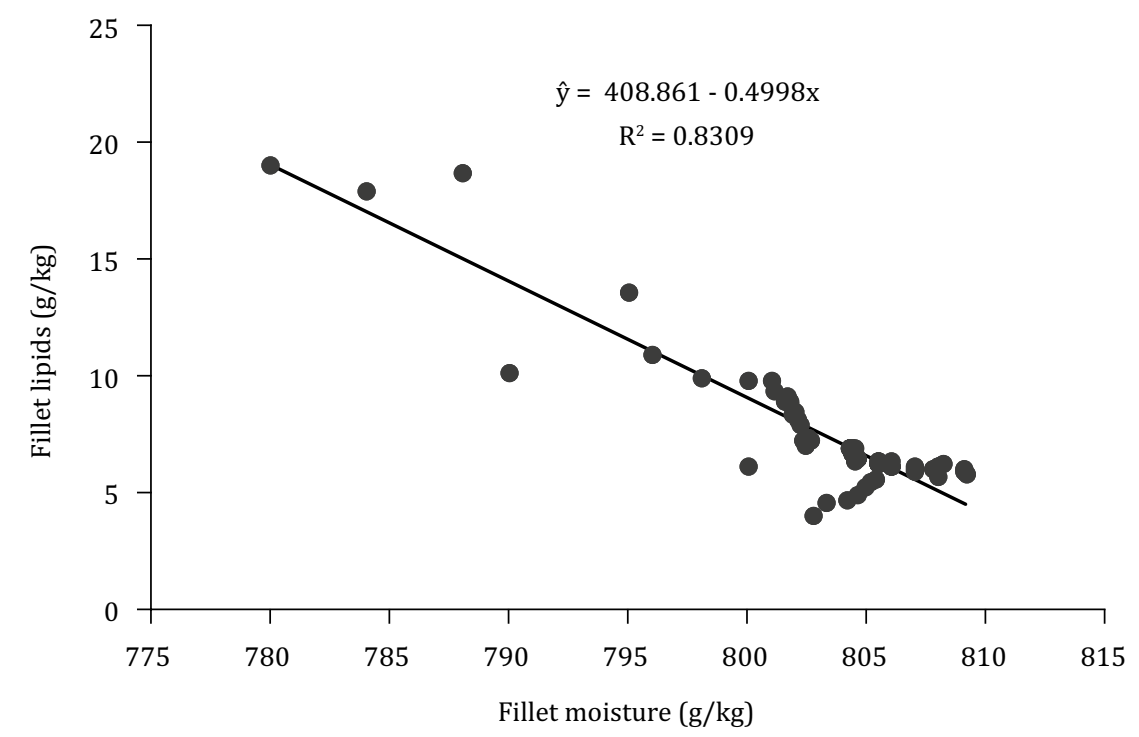

Figure 2 - Relationship between content of moisture and lipids in the fillet of market-sized wild traíra, Hoplias lacerdae. 
was quite variable, from 32.06 to $61.19 \mathrm{~cm}$, because fish at different stages were used, and allometric growth was obtained.

In this study, fish were not classified considering sex to mimic practical conditions, because there are no reliable visually morphological differences to identify sex of $H$. malabaricus during fishing and marketing. To date, higher mathematical adjustment was obtained to describe length:weight ratio of fish in this study; besides, combined sexes were used. This relationship allows estimating the body weight from length and also extrapolates gutted weight and fillet weight of fish during marketing.

In the present study, the relationship between body weight and fillet weight was high, while the relationship between body weight and fillet yield was low. Similar results were previously observed in Nile tilapia (Oreochromis niloticus; Rutten et al., 2004), rainbow trout (Oncorhynchus mykiss; Rasmussen and Ostenfeld, 2000), catfish (Pangasianodon hypophthalmus; Sang et al., 2009), and European sea bass (Dicentrarchus labrax; Vandeputte et al., 2017).

The mean value of dressed $(938.63 \mathrm{~g} / \mathrm{kg})$ and fillet $(425.23 \mathrm{~g} / \mathrm{kg})$ yields of wild H. malabaricus observed in this study approximated the $928.1 \mathrm{~g} / \mathrm{kg}$ and $419.9 \mathrm{~g} / \mathrm{kg}$ (skin-on fillet), respectively, observed in piava, Leporinus obtusidens by Geraldo et al. (2015); similarly, it approximated the $923.5 \mathrm{~g} / \mathrm{kg}$ of dressed yield obtained in rainbow trout (Souza et al., 2015) and $914.4 \mathrm{~g} / \mathrm{kg}$ in surubin, Pseudoplatystoma spp (Fantini et al., 2014). However, higher values of fillet yield (skin-on) were observed in European sea bass ( $457.0 \mathrm{~g} / \mathrm{kg}$ ), gilthead sea bream (Sparus aurata; $477.3 \mathrm{~g} / \mathrm{kg}$ ), and rainbow trout (Testi et al., 2006).

In the present study, the high variation observed in fillet yield (358.93 to $465.11 \mathrm{~g} / \mathrm{kg}$ ) is in agreement to previously described in the same fish species $(348.2$ to $538.5 \mathrm{~g} / \mathrm{kg}$ ) by Santos et al. (2001). Fillet yield varies among fish species (Rasmussen and Ostenfeld, 2000; Testi et al., 2006) and is markedly affected by nutrition (Lanari et al., 1999; Geraldo et al., 2015) and processing method (Margeirsson et al., 2007).

Linear regression analysis has been extensively used for predicting body component because of the very high relationships found between body weight and proximate composition of fish. In general, lower variations of crude protein and ash are observed, while humidity and crude lipid are quite variable (Breck, 2014). As fish grows in size, it deposits relatively more fat than other tissues, as previously reported for other fish species (Geraldo et al., 2015).

In the present study, lower mean value of body crude lipids $(7.41 \pm 0.59 \mathrm{~g} / \mathrm{kg})$ was observed in the fillets of fish, in agreement with the $8.4 \mathrm{~g} / \mathrm{kg}$ previously described for this same fish species (Santos et al., 2001), and higher than 5.6 to $6.4 \mathrm{~g} / \mathrm{kg}$ found in pirarucu, Arapaima gigas (Fogaça et al., 2011). However, higher values of crude lipids ranging from 39 to $61 \mathrm{~g} / \mathrm{kg}$ in fillets of sea bass (Lanari et al., 1999), 79.6 to $90.4 \mathrm{~g} / \mathrm{kg}$ in rainbow trout (Souza et al., 2015), and 85 to $218 \mathrm{~g} / \mathrm{kg}$ in Atlantic salmon, Salmo salar (Mørkøre et al., 2001) were described.

Body composition of fish is affected by many factors such as fish species, environmental variables, dietary factors, and body size (Breck, 2014). Determining body component in relation to fish size is strongly associated to meat quality and is considered an important attribute used by consumers. In addition, proximate composition is also used to select appropriate species and genetic improvement programs (Neira et al., 2004; Quinton et al., 2005; Tobin et al., 2006; Navarro et al., 2009) to improve meat quality for human consumption.

The content of moisture in whole body is a good indicator of the relative content of lipids and energy, and low percentage of moisture is associated to high content of lipids and energy (Dempson et al., 2004). In this study, positive linear relationship between body weight and lipid contents in the fillet was observed; however, moisture and crude protein content of fillet linearly decreased with the increase of body weight. Similarly, increased lipid content with increasing size of fish was described in rainbow trout (Souza et al., 2015), matrinxã (Brycon cephalus; Macedo-Viegas et al., 2000), and African catfish (Clarias gariepinus; Salisu and Faturoti, 2016).

R. Bras. Zootec., 48:e20170176, 2019 
Determining fillet traits and composition are important to address requirements of specific market according to sensory perception of consumers and enables the fish industry and fish farmers to adapt to the demands of consumers (Tobin et al., 2006).

The technical difficulty, high cost, and time associated to continuing chemical analysis emphasizes the importance of developing mathematical models to predict fillet traits and composition of fish with a high accuracy.

\section{Conclusions}

Fillet yield and composition of H. malabaricus varies according to body weight and dressed weight, fillet weight, and fillet composition and can be estimated by first-order linear regression analysis. No reliable equations were found to estimate dressed yield and fillet yield of market-sized H. malabaricus using linear regression analysis.

\section{Conflict of Interest}

The authors declare no conflict of interest.

\section{Author Contributions}

Investigation: W.M. Furuya. Methodology: M. Michelato, T.P. Cruz, A.V. Urbich, J.W.A. Ribeiro and D.C. Batista. Project administration: V.R.B. Furuya. Supervision: V.R.B. Furuya and A.L. Salaro. Validation: W.M. Furuya. Writing-original draft: M. Michelato and W.M. Furuya. Writing-review \& editing: W.M. Furuya.

\section{References}

AOAC - Association of Official Analytical Chemists. 2010. Official methods of anlaysis. 18th ed. AOAC, Gaithersburg.

Azam, K.; Ali, M. Y.; Asaduzzaman, M.; Basher, M. Z. and Hossain, M. M. 2004. Biochemical assessment of selected fresh fish. Journal of Biological Sciences 4:9-10.

Balboni, L.; Colautti, D. C. and Baigún, C. R. M. 2011. Biology of growth of Hoplias aff. malabaricus (Bloch, 1794) in a shallow pampean lake (Argentina). Neotropical Ichthyology 9:437-444. https://doi.org/10.1590/S1679-62252011000200022

Bertollo, L. A. C.; Born, G. G.; Dergam, J. A.; Fenocchio, A. S. and Moreira-Filho, O. 2000. A biodiversity approach in the neotropical Erythrinidae fish, Hoplias malabaricus. Karyotypic survey, geographic distribution of cytotypes and cytotaxonomic considerations. Chromosome Research 8:603-613. https://doi.org/10.1023/A:1009233907558

Bialetzki, A.; Nakatani, K.; Sanches, P. V.; Baumgartner, G.; Makrakis, M. C. and Taguti, T. L. 2008. Desenvolvimento inicial de Hoplias aff. malabaricus (Bloch, 1794) (Osteichthyes, Erythrinidae) da planície alagável do alto rio Paraná, Brasil. Acta Scientiarum - Biological Sciences 30:141-149. https://doi.org/10.4025/actascibiolsci.v30i2.3608

Braga, F. M. S. 1986. Estudo entre fator de condição e relação peso-comprimento para alguns peixes marinhos. Revista Brasileira de Biologia 46:339-346.

Breck, J. E. 2014. Body composition in fishes: body size matters. Aquaculture 433:40-49. https://doi.org/10.1016/j. aquaculture.2014.05.049

Carvalho, L. N.; Fernandes, C. H. V. and Moreira, V. S. S. 2003. Alimentação de Hoplias malabaricus (Bloch, 1794) (Osteichthyes, Erythrinidae) no rio Vermelho, Pantanal Sul Mato-Grossense. Revista Brasileira de Zoociências 4:227-236.

Chaves, M. F.; Torelli, J.; Targino, C. H. and Crispim, M. C. 2011. Dinâmica reprodutiva e estrutura populacional de Hoplias aff. malabaricus (Bloch, 1794) (Characiformes, Erythrinidae), em açude da Bacia do Rio Taperoá, Paraíba. Biotemas 22:85-89. https://doi.org/10.5007/2175-7925.2009v22n2p85

Cherif, M.; Zarrad, R.; Gharbi, H.; Missaoui, H. and Jarboui, O. 2008. Length-weight relationships for 11 fish species from the Gulf of Tunis (SW Mediterranean Sea, Tunisia). Pan-American Journal of Aquatic Sciences 3:1-5.

Cioffi, M. B.; Martins, C.; Centofante, L.; Jacobina, U. and Bertollo, L. A. C. 2009. Chromosomal variability among allopatric populations of erythrinidae fish Hoplias malabaricus: Mapping of three classes of repetitive DNAs. Cytogenetic and Genome Research 125:132-141. https://doi.org/10.1159/000227838 
Dempson, J. B.; Schwarz, C. J.; Shears, M. and Furey, G. 2004. Comparative proximate body composition of Atlantic salmon with emphasis on parr from fluvial and lacustrine habitats. Journal of Fish Biology 64:1257-1271. https://doi. $\operatorname{org} / 10.1111 / \mathrm{j} .0022-1112.2004 .00389 . x$

Dumas, A.; France, J. and Bureau, D. 2010. Modelling growth and body composition in fish nutrition: Where have we been and where are we going? Aquaculture Research 41:161-181. https://doi.org/10.1111/j.1365-2109.2009.02323.x

Fantini, L. E.; Oliveira, C. A. L.; Rodrigues, R. A.; Oliveira, A. M. S.; Ushizima, T. T. and Campos, C. M. 2014. Rendimento de carcaça de surubins Pseudoplatystoma spp. produzidos em viveiros sob diferentes densidades de estocagem. Semina: Ciências Agrárias 35:2769-2780.

Fogaça, F. H. S.; Oliveira, E. G.; Carvalho, S. E. Q. and Santos, F. J. S. 2011. Rendimento e composição do filé de pirarucu em diferentes classes de peso. Acta Scientiarum - Animal Sciences 33:95-99.

Geraldo, A. M. R.; Cunha, L.; Hoshiba, M. A.; Cardoso, M. S.; Silva, V. C. and Tamajusuku, A. S. K. 2015. Fillet and carcass yield and fillet chemical composition of piava from fish farming and from the wild. Boletim do Instituto de Pesca 41(Special):743-749.

Gjedrem, T. 2000. Genetic improvement of cold-water fish species. Aquaculture Research 31:25-33. https://doi. org/10.1046/j.1365-2109.2000.00389.x

Gulland, J. A. 1983. Fish stock assessment: a manual of basic methods. FAO/Wiley Series on Food and Agriculture Vol. 1. Willey Interscience, Chichester.

Hunter, B. J. and Roberts, D. C. K. 2000. Potential impact of the fat composition of farmed fish on human health. Nutrition Research 20:1047-1058. https://doi.org/10.1016/S0271-5317(00)00181-0

Lanari, D.; Poli, B. M.; Ballestrazzi, R.; Lupi, P.; D’Agaro, E. and Mecatti, M. 1999. The effects of dietary fat and NFE levels on growing European sea bass (Dicentrarchus labrax L.). Growth rate, body and fillet composition, carcass traits and nutrient retention efficiency. Aquaculture 179:351-364. https://doi.org/10.1016/S0044-8486(99)00170-2

Macedo-Viegas, E. M.; Scorvo, C. M. D. F.; Vidotti, R. M. and Secco, E. M. 2000. Effect of weight classes on body composition and processing yield of cultivated matrinxã (Brycon cephalus). Acta Scientiarum. Animal Sciences 22:725-728.

Margeirsson, S.; Jonsson, G. R.; Arason, S. and Thorkelsson, G. 2007. Influencing factors on yield, gaping, bruises and nematodes in cod (Gadus morhua) fillets. Journal of Food Engineering 80:503-508. https://doi.org/10.1016/j. jfoodeng.2006.05.032

Marques, D. K. A.; Gurgel, H. C. B. and Lucena, I. 2001. Época de reprodução de Hoplias malabaricus Bloch, Erythrinidae) da barragem do rio Gramame, Alhandra. Revista Brasileira de Zoociências 1794:61-67.

Mørkøre, T.; Vallet, J. L.; Cardinal, M.; Gomez-Guillen, M. C.; Montero, P.; Torrisen, O. J.; Norvedt, R.; Sigurgisladottir, S. and Thomassen, M. S. 2001. Fat content and fillet shape of Atlantic salmon: Relevance for processing yield and quality of raw and smoked products. Journal of Food Science 66:1348-1354. https://doi.org/10.1111/j.1365-2621.2001.tb15213.x

Mozaffarian, D. and Rimm, E. B. 2006. Fish intake, contaminants, and human health: evaluating the risks and the benefits. JAMA: the Journal of the American Medical Association 296:1885-1899. https://doi.org/10.1001/jama.296.15.1885

Navarro, A.; Zamorano, M. J.; Hildebrandt, S.; Ginés, R.; Aguilera, C. and Afonso, J. M. 2009. Estimates of heritabilities and genetic correlations for growth and carcass traits in gilthead seabream (Sparus auratus L.), under industrial conditions. Aquaculture 289:225-230. https://doi.org/10.1016/j.aquaculture.2008.12.024

Neira, R.; Lhorente, J. P.; Araneda, C.; Díaz, N.; Bustos, E. and Alert, A. 2004. Studies on carcass quality traits in two populations of Coho salmon (Oncorhynchus kisutch): Phenotypic and genetic parameters. Aquaculture 241:117-131. https://doi.org/10.1016/j.aquaculture.2004.08.009

Querol, M. V. M.; Queroll, E.; Pessano, E.; Azevedo, C. L. O.; Tomassoni, D.; Brasil, L. and Lopes, P. 2003. Reprodução natural e induzida de Hoplias malabaricus (BLOCH, 1794), em tanques experimentais, na região de Uruguaiana, Pampa brasileiro. Biodiversidade Pampeana 1:46-57.

Quinton, C. D.; McMillan, I. and Glebed, B. D. 2005. Development of an Atlantic salmon (Salmo salar) genetic improvement program: Genetic parameters of harvest body weight and carcass quality traits estimated with animal models. Aquaculture 247:211-217. https://doi.org/10.1016/j.aquaculture.2005.02.030

Rasmussen, R. S. and Ostenfeld, T. H. 2000. Effect of growth rate on quality traits and feed utilisation of rainbow trout (Oncorhynchus mykiss) and brook trout (Salvelinus fontinalis). Aquaculture 184:327-337. https://doi.org/10.1016/ S0044-8486(99)00324-5

Ricker, W. E. 1973. Linear regressions in fishery research. Journal of the Fisheries Research Board of Canada 30:409-434 https://doi.org/10.1139/f73-072

Rutten, M. J. M.; Bovenhuis, H. and Komen, H. 2004. Modeling fillet traits based on body measurements in three Nile tilapia strains (Oreochromis niloticus L.). Aquaculture 231:113-122. https://doi.org/10.1016/j.aquaculture.2003.11.002

Salisu, A. A. A. and Faturoti, E. O. 2016. Effect of different weight classes of processed Clarias gariepinus on yields of fish fillet and fishmeal production. International Journal of Science and Research 5:2013-2016. 
Sang, N. V.; Thomassen, M.; Klemetsdal, G. and Gjøen, H. M. 2009. Prediction of fillet weight, fillet yield, and fillet fat for live river catfish (Pangasianodon hypophthalmus). Aquaculture 288:166-171. https://doi.org/10.1016/j.aquaculture.2008.11.030

Santos, A. B.; Melo, J. F. B.; Lopes, P. R. S. and Malgarim, M. B. 2001. Composição química e rendimento do filé da traíra (Hoplias malabaricus). Revista da Faculdade de Zootecnia, Veterinária e Agronomia 7/8:140-150.

Silva, T. T. M.; Araújo, T. A. T. and Bicudo, A. J. A. 2013. First report of albinism in trahira Hoplias malabaricus from Brazil. Boletim do Instituto de Pesca 39:457-460.

Souza, M. L. R.; Macedo-Viegas, E. M.; Zuanon, J. A. S.; Carvalho, M. R. B. and Goes, E. S. R. 2015. Processing yield and chemical composition of rainbow trout (Oncorhynchus mykiss) with regard to body weight. Acta Scientiarum. Animal Sciences 37:103-108. https://doi.org/10.4025/actascianimsci.v37i2.24165

Testi, S.; Bonaldo, A.; Gatta, P. P. and Badiani, A. 2006. Nutritional traits of dorsal and ventral fillets from three farmed fish species. Food Chemistry 98:104-111. https://doi.org/10.1016/j.foodchem.2005.05.053

Tobin, D.; Kause, A.; Mäntysaari, E. A.; Martin, S. A. M.; Houlihan, D. F.; Dobly, A.; Kiessling, A.; Rungruangsak-Torrissen, K.; Ritola, O. and Ruohonen, K. 2006. Fat or lean? The quantitative genetic basis for selection strategies of muscle and body composition traits in breeding schemes of rainbow trout (Oncorhynchus mykiss). Aquaculture 261:510-521. https://doi.org/10.1016/j.aquaculture.2006.07.023

Torres, L. M.; Zambiazi, R. C.; Chiattone, P. V.; Fonseca, T. P. and Costa, C. S. 2012. Composição em ácidos graxos de traíra (Hoplias malabaricus) e pintadinho (sem classificação) provenientes da Região Sul do Rio Grande do Sul e Índia Morta no Uruguai. Semina:Ciencias Agrarias 33:1047-1058.

Vandeputte, M.; Puledda, A.; Tyran, A. S.; Bestin, A.; Coulombet, C.; Bajek, A.; Baldit, G.; Vergnet, A.; Allal, F.; Bugeon, J. and Haffray, P. 2017. Investigation of morphological predictors of fillet and carcass yield in European sea bass (Dicentrarchus labrax) for application in selective breeding. Aquaculture 470:40-49. https://doi.org/10.1016/j.aquaculture.2016.12.014

Weatherley, A. S. and Gill, H. S. 1987. The biology of fish growth. Academic Press, London. 